\title{
MENINGKATKAN KOMPETENSI GURU DALAM ADMINISTRASI PENILAIAN MELALUI SUPERVISI AKADEMIK DI SDN 116884 SEI KEBARA DESA
}

\author{
oleh \\ Suria Marpaung \\ inazriel5@gmail.com \\ SD Negeri 116884 Sei Kebara \\ Desa Torgamba Kec. Torgamba Kabupaten Labuhanbatu Selatan
}

\begin{abstract}
Abstrak-Kompetensi dalam menyusun administrasi penilaian masih menjadi masalah yang senantiasa ditemukan di berbagai sekolah, tidak terkecuali SDN 116884 Sei Kebara Desa Torgamba Kec. Torgamba Kab. Labuhanbatu Selatan. Oleh karena itu, penelitian tindakan sekolah (PTS) ini ditujukan untuk meningkatkan kompetensi pedagogik guru-guru di SDN 116884 Sei Kebara dalam menyusun administrasi penilaian melalui supervisi akademik. Jenis penelitian yang digunakan dalam penelitian ini adalah penelitian tindakan sekolah. Kegiatan dalam penelitian ini terdiri atas tahapan perencanaan tindakan, pelaksanaan tindakan, observasi, dan refleksi.Teknik pengumpulan data menggunakan teknik obeservasi kelas dengan menggunakan alatpenilaian kemampuan guru (APKG). Analisis data yang digunakan adalah teknik analisis deskriptif komparatif. Hal tersebut dapat dibuktikan dengan adanya peningkatan nilai pasca adanya tindakan yaitu 5 guru $(45,46 \%)$ pada kategori baik sekali, 4 guru $(36,36 \%)$ berada pada kategori baik dan 2 guru (18,18\%) berada pada kategori cukup.Peneliti menyimpulkan bahwa peningkatan kompetensi guru-guru dalam menyusun administrasi penilaian dalam pembelajaran di SDN 116884 Sei Kebara Desa Torgamba, Kec. Torgamba Kab. Labuhanbatu Selatan sebesar 26,82\%.
\end{abstract}

\section{Kata kunci: supervisi akademik, kompetensi pedagogik}

\section{A. PENDAHULUAN}

Kualitas sumber daya manusia sangat menentukan nasib sebuah bangsa di masa depan. Berbagai kajian sudah membuktikan bahwa pendidikan merupakan instrument paling tepat untuk memperbaiki sumber daya manusia. Untuk memperbaiki sumberdaya manusia tersebut maka proses pembelajaran di sekolah harus senantiasa ditingkatkan. Dengan kata lain, meningkatkan kualitas pembelajaran di kelas dengan sendirinya akan meningkatkan sumber daya manusia. Dalam meningkatkan kualitas sumberdaya manusia, guru mempunyai peran yang sangat penting. Keberhasilan siswa dalam belajar sangat dipengaruhi oleh bagaimana cara guru mengajar. Guru tidak hanya berfungsi mentransfer pengetahuan saja tetapi juga bertugas untuk memberikan keterampilan, merubah perilaku peserta didik. Untuk itu diperlukan guru yang profesional dalam pendidikan. Oleh karena itu kompetensi guru harus terus menerus dibina dan dikembangkan sehingga guru mampu menghasilkan pendidikan yang bermutu.

Dalam UUNomor 14 Tahun 2005 tentang Guru dan Dosen disebutkan bahwa 
seorang guru adalah pendidik profesional dengan tugas utama mendidik, mengajar, membimbing, mengarahkan, melatih, menilai, dan mengevaluasi peserta didik pada jalur pendidikan formal, pendidikan dasar, dan pendidikan menengah. Sementara itu, Permendiknas No. 16 Tahun2007 disebutkan bahwa kompetensi guru SD/MI antara lain: 1) memahami prinsip-prinsip penilaian dan evaluasi proses dan hasil belajar sesuai dengan karakteristik lima mata pelajaran SD/MI; 2) menentukan aspekaspek proses dan hasil belajar yang penting untuk dinilai dan dievaluasi sesuai dengan karakteristik lima mata pelajaran SD/MI; 3) menentukan prosedur penilaian dan evaluasi proses dan hasil belajar; 4) mengembangkan instrumen penilaian dan evaluasi proses dan hasil belajar; 5) mengadministrasikan penilaian proses dan hasil belajar secara berkesinambungan dengan mengunakan berbagai instrumen; 6) menganalisis hasil penilaian proses dan hasil belajar untuk berbagai tujuan; dan 7) melakukan evaluasi proses dan hasil belajar.

Berbagai kajian terbaru menunjukkan bahwa implementasi di kelas atau di sekolah tidak sejalan dengan apa yang diharapkan. Dengan kata lain masih jauh dari harapan atau belum sepenuhnya komponen itu dilaksanakan. Realitas yang ada di SD 116884 Sei Kebara Desa Torgamba, Kec. Torgamba Kab. Labuhanbatu Selatan menunjukkan bahwa guru masih belum kompeten dalam menyusun administrasi penilaian pembelajarandengan baik. Hal ini diperkuat oleh temuan pada kajian awal yang dilakukan oleh kepala sekolah yang menyebutkan bahwa terdapat 4 guru(36,36\%) yang berada pada skor kurang dari 51-60 atau kategori kurang.

Guru belum melaksanakan penilaian afektif, belum melaksanakan tugas secara tertruktur, belum melaksanakan program dan pelaksanaan remidial serta belum melakukan analisis hasil ulangan. Selain itu, terdapat 5 guru $(45,46 \%)$ yang berada pada skor 6175atau kategori cukup. Data ini menunjukkan guru belum membuat program dan pelaksanaan remedial, belum melakukan analisis hasil ulangan serta belum membuat instrumen tes dan bank soal. Terakhir, ada 2 guru $(18,18 \%)$ yang berada pada skor $76-90$ atau kategori Baik.

Uraian kondisi faktual di atas membuat peneliti berupaya melakukan perbaikan dalam rangka peningkatan kompetensi pedagogik menggunakan supervisi akademik. Menurut Arikunto Suharsimi (2006:5) kegiatan supervisi ada dua jenis yaitu supervisi akademik dan supervisi administrasi.Dari dua kegiatan supervisi yang ada, supervisi akademik merupakan kegiatan yang sangat potensial untuk meningkatkan kompetensi pedagogik guru .Potensi supervisi akademik tersebut oleh karena lingkupnya langsung pada kegiatan pembelajaran.

Sedangkan yang menjadi fokus dalam supervisi akademik adalah mengkaji, menilai,memperbaiki, meningkatkan, dan mengembangkan mutu kegiatan belajar mengajar yang dilakukan guru melalui pendekatan bimbingan dan konsultasi dalam nuansa dialog profesional.Merujuk pada uraian latar belakang di atas, permasalahan penelitian yang akan dipecahkan adalah apakah supervisi akademik dapat meningkakan kompetensi pedagogik guru 
SD dan bagaimana supervisi akademikdapat meningkatkan kompetensi pedagogik guru SD.

\section{Kajian Teoritis}

\section{Komptensi Guru}

Pada dasarnya guru merupakan tenaga professional yang bertugas merencanakan dan melaksanakan proses pembelajaran, menilai hasil pembelajaran serta melakukan pembimbingan kepada peserta didik. Hal ini seperti yang tercantum dalam UndangUndang Nomor 14 Tahun 2005 yang menyebutkan bahwa guru merupakanpendidik profesional yang mempunyai mendidik, mengajar, membimbing, mengarahkan, melatih, menilai, dan mengevaluasi peserta didik. Guru yang ingin menjadi profesional memerlukan kompetensi atau kemampuan atau keterampilan dalam melaksanakan tugasnnya.Kompetensi guru berkaitan dengan profesionalisme, yaitu guru yang profesional adalah guru yang kompeten (berkemampuan).

Lebih dari itu, kompetensi profesionalisme guru dapat diartikan sebagai kemampuan dan kewenangan guru dalam menjalankan profesi keguruannya dengan kemampuan tinggi. Daryanto dan Tasrial (2011:1) mengatakan bahwa kompetensi merupakan seperangkat pengetahuan, keterampilan, dan perilkau yang harus dimiliki, dihayati, dan dikuasai oleh guru dalam melaksanakan tugas profesionalannya. Hal ini sejalan dengan Peraturan Pemerintah RI No 19 Tahun 2005 mengenai Standar Nasional Pendidikan menyebutkan bahwa guru memiliki 4 kompetensi. Pertama, kompetensi pedagogik, yakni kemampuan mengelola pembelajaran yang meliputi pemahaman terhadap peserta didik, perancangan dan pelaksanaan pembelajaran, evaluasi hasil belajar, dan pengembangan peserta didik untuk mengaktualisasikan berbagai potensi yang dimilikinya.

Kedua, kompetensi kepribadian, yakni kemampuan kepribadian yang mantap, stabil, dewasa, arif, dan berwibawa, mampu menjadi teladan bagi peserta didik, serta berakhlak mulia. Ketiga ialah kompetensi professional, yakni kemampuan penguasaan materi pembelajaran secara luas dan mendalam untuk membimbing peserta didik dan yang keempat adalah kompetensi sosial, yakni kemampuan pendidik sebagai bagian dari masyarakat untuk berkomunikasi dan bergaul secara efektif dengan peserta didik, sesama pendidik, tenaga kependidikan, orangtua/wali peserta didik, dan masyarakat sekitar. Penelitian ini sendiri fokus kepada kompetensi pedagogik menjadi salah satu kompetensi yang perlu dikembangkan karena sesuai dengan kebutuhan seperti telah dipaparkan pada bagian latar belakang masalah.

(2004) yang menyebutkan bahwa kompetensi pedagogik merupakan kemampuan guru dalam merencanakan program belajar mengajar, kemampuan melaksanakan interaksi atau mengelola proses belajar mengajar, dan kemampuan melakukan penilaian. Tidak hanya itu, Permendiknas No 16 Tahun 2007 tentang Standar Kualifikasi Akademik dan Kompetensi guru, memaparkan 10 isi standar kompetensi pedagogik. Pertama adalah penguasaanterhadap karakteristik 
peserta didik dari aspek fisik, moral, sosial, kultural, emosional, dan intelektual.

Kedua, menguasai teori belajar dan prinsip-prinsip pembelajaran yang mendidik. Berikutnya mengembangkan kurikulum yang terkait dengan mata pelajaran/bidang pengembangan yang diampu. Kemudian, guru mampu menyelenggarakan pembelajaran yang mendidik. Lebih dari itu, guru kompeten dalam memanfaatkan teknologi informasi dan komunikasi untuk kepentingan pembelajaran. Keenam ialah kemampuan untuk memfasilitasi pengembangan potensi peserta didik untuk mengak-tualisasikan berbagai potensi yang dimiliki. Berikutnya adalah mampu berkomunikasi secara efektif, empatik, dan santun dengan peserta didik. Kemudian, menyelenggarakan penilaian dan evaluasi proses dan hasil belajar,memanfaatkan hasil penilaian dan evaluasi untuk kepentingan pembelajaran, dan guru kompeten dalam melakukan tindakan reflektif untuk peningkatan kualitas pembelajaran.

Dalam rangka memberikan assesmen yang akurat, Dirjen PMPTK (2012:71) merumuskan pedoman pengukuran kompetensi pedagogik yaitu: 1) menyusun alat penilaian sesuai dengan tujuan pembelajaran (RPP), 2) melaksanakan penilaian, 3) menganalisa hasil penilaian, 4) memanfaatkan masukan dari peserta didik dan merefleksikan, dan 5) memanfaatkan hasil penilaian sebagai penyusunan rancangan pembelajaran selanjutnya.Dengan memahami elaborasi definisi kompetensi dan standar kompetensi pedagogik diatas,dapat disimpulkan bahwa kompetensi guru SD pada hakekatnya merupakan perwujudan dari kemampuan, pengetahuan, dan keterampilan yang dimiliki guru SD dalam menjalankan tugas sebagai pendidik untuk mewujudkan pembelajaran yang berkualitas.

\section{Hakikat Supervisi Akademik}

Berbagai pakar memiliki pendapat tentang supervisi akademik. Secara sederhana, supervisi merupakan suatu kegiatan yang dilakukan dalam rangka memperbaiki mutu pembelajaran. Menurut Sahertian (2010:19) supervise adalah usaha memberi layanan kepada guru-guru baik secara individual maupun secara kelompok dalam usaha memperbaiki pengajaran. Sedangkan Ngalim Purwanto (2013:26) menjelaskan bahwa supervisi merupakan akivitas pembinaan yang direncanakan untuk membantu guru dan pegawai sekolah dalam melakukan pekerjaan secara efektif.

Sejalan dengan Sahertian (2010:19), Ngalim Purwanto (2013:26), dan Good Carter dikutip oleh Daryanto (2010:170) menjelaskan bahwa supervisi merupakan usaha dari pejabat sekolah dalam memimpin guru dan tenaga pendidikan lain untuk memperbaiki pengajaran, memberi stimulasi pertumbuhan dan perkembangan guru, merevisi tujuan pendidikan, bahan pengajaran, metode mengajar hingga evaluasi pengajaran. Suhertian (2000: 19) menjelaskan bahwa secara umum supervise memiliki tujuan untuk memberikan bantuan dalam mengembangkan situasi belajar mengajar yang lebih baik, melalui usaha peningkatan profesionalitas dalam mengajar; menilai kemampuan guru sebagai pendidik dan pengajar dalam bidang masing-masing guna membantu mereka melakukan perbaikan dan jika diperlukan dengan 
menunjukkan kekurangan-kekurangan untuk diperbaiki.

Sedangkan Sudjana, dkk (2011:19) menyebutkan bahwa Supervisi akademik merupakan fungsi pengawas berkenaan dengan aspek pelaksanaan tugas pembinaan, pemantauan, penilaian dan pelatihan professional guru dalam: (1) merencanakan pembelajaran;

(2) melaksanakan pembelajaran; (3) menilai hasil pembelajaran; (4) membimbing dan melatih peserta didik, dan (5) melaksanakan tugas tambahan yang melekat pada pelaksanaan kegiatan pokok sesuai dengan beban kerja guru. Oleh karena itu dalam pelaksanaannya, supervisi harus dilakukan secara teratur dan berkesinambungan sehingga kualitas pembelajaran dapat meningkat.

Berdasarkan pendapat yang telah dikemukaakan diatas dapat disimpulkan bahwa supervisi merupakan pemberian layanan dan bantuan untuk meningkatkan kualitas mengajar guru di kelas dengan tujuan untuk meningkatkan kualitas belajar siswa yang dimulai dari perencanaan pembelajaran, pelaksanaan kegiatan pembelajaran, mengevaluasi pembelajaran sampai melakukan refleksi. Selain untuk memperbaiki kemampuan mengajar supervisi juga bertujuan untuk pengembangan potensi kualitas guru.

Sejalan dengan pendapat diatas, Permendiknas no. 39 tahun 2009 menyebutkan bahwa ruang lingkup supervisi akademik meliputi: a) membina guru dalam merencanakan, melaksanakan dan menilaia proses pembelajaran, b) memantau pelaksanaan standar isi, c) memantau pelaksanaan standar proses, d)memantau pelaksanaan standar kompetensi kelulusan, e) memantau pelaksanaan standar tenaga pendidik dan f) memantau pelaksanaan standar penilaian. Peningkatkan mutu guru yang berkualitas perlu dilakukan secara terprogram, terstruktur dan berkelanjutan melalui pembinaan profesional oleh kepala sekolah.

Melalui supervisi akademik kepala sekolah mampu menampung berbagai masalah yang dihadapi oleh guru dalam proses pembelajaran untuk dapat menemukan cara-cara pemecahan permasalahan. Esensi supervisi akademik bukanlah menilai unjuk kerja guru dalam mengelola proses pembelajaran, melainkan untuk membantu guru mengembangkan kemampuan profesionalismenya. Walaupun dalam prosesnya tidak lepas dari kegiatan menilai guru.Wajar jika supervisi akademik dianggap sebagai penilaian guru dikarenakan supervisi lebih banyak dilakukan dalam bentuk pengamatan mengajar guru.

Penilaian dalam mengelola proses pembelajaran sebagai suatu proses pemberian estimasi kualitas unjuk kerja guru dalam mengelola proses pembelajaran, merupakan bagian yang tak terpisahkan dari serangkaian kegiatan supervisi. Bertolak dari hal tersebut, kebijakan untuk meningkatkan mutu pendidikan pada hakikatnya merupakan keputusan yang strategis. Mutu pendidikan pada umumnya dapat dilihat dari dua segi yaitu segi proses dan segi produk. Dari segi proses, pendidikan dapat disebut bermutu apabila proses pembelajaran berlangsung secara efektif sehingga menghasilkan produk yang berkualitas.

Sedangkan dari segi produk, hasil pendidikan disebut bermutu jika peserta 
didik menunjukkan tingkat penguasaan yang tinggi terhadap tugas-tugas belajar yang dinyatakan dalam prestasi belajar; hasil pendidikan sesuai dengan kebutuhan peserta didik dalam kehidupannya; hasil pendidikan yang sesuai atau relevan dengan tuntutan lingkungan, khususnya dunia kerja (Depdikbud, 1996).

Berpijak pada ruang lingkup supervisi seperti telah dipaparkan diatas, maka penelitian ini dilakukan untuk mengembangkan kompetensi guru dalam merencanakan, melaksanakan dan menilai proses pembelajaran melalui supervisi akademik. Merancang penilaian merupakan kegiatan guru dalam memutuskan kompetensi dasar yang akan diukur, cakupan bahan, jenis dan bentuk penilaian. Hasil kegiatan merancang penilaian ini dituangkan dalam bentuk kisi-kisi soal. Format kisi-kisi soal umumnya dalam bentuk tabel enam kolom.

Kolom pertama berisi kompetensi dasar (KD), kolom kedua indikator pencapaian kompetensi, kolom ketiga ranah kompetensi belajar (misalnya ranah kognitif C1, C2, C3 dan seterusnya), kolom keempat berisi pernyataan tingkat kesukaran soal (apakah soal mudah, sedang, sukar), kolom kelima berisi keputusan tentang jenis/bentuk penilaian yang digunakan (misalnya soal uraian, pilihan ganda, menjodohkan dan lain-lain), kolom terakhir, yaitu kolom keenam berisi nomor soal. Setelah selesai menyusun kisi-kisi soal, kemudian melakukan penyusunan naskah sosal sesuai dengan kisis-kisi.

Kegiatan melaksanakan penilaian berarti mengukur penguasaan materi pelajaran menggunakan soal yang telah disusun. Pelassanaan penilaian bias dilakukan sesuai dengan jadwal yang telah ditetapkan atau menggunakan jam pelajaran. Kegiatan terakhir setelah melaksanakan penilaian adalah melakukan kegiatan persekoran dengan memeriksa hasil tes siswa. Skor yang telah diperoleh kemudian dilakukan pembandingan dengan kriteria tertentu; misalnya kriteria ketuntasan belajar minimal (KKM).

\section{B. METODEPENELITIAN}

Penelitian tindakan sekolah (PTS) ini dilakukan di SD 116884 Sei Kebara Desa Torgamba Semester 1 Tahun Pelajaran 2018/2019. Pelaksanaan penelitian tindakan sekolah ini dilakukan melalui tahapan penyusunan proposal penelitian, penyusunan instrument, pelaksanaan tindakan dalam rangka pengumpulan data, analisis data dan pembahasan hasil penelitian serta penyusunan laporan PTS. Subyek yang dilibatkan dalam penelitian tindakan sekolah ini adalah guru kelas VI.Sumber data primer berasal dari hasil pengukuran variabel penelitian tindakan sekolah berikut skor kemampuan guru menyusun administrasi penilaian pembelajaran.

Peneliti melakukan pengumpulan data dengan menggunakan teknik obeservasi kelas. Instrumen observasi yang digunakan adalah alat penilaian kemampuan guru (APKG) berupa: Instrument penilaian administrasi pembelajaran dan kisi-kisi instrumen pengukuran. Instrument penilaian administrasi pembelajaran. mencakup 10 komponen, yaitu: (1) Buku nilai/Daftar nilai, (2) Pelaksaan Tes (kognitif): UH, UTS, UAS, (3) Penugasan terstruktur (PT), (4) Kegiatan mandiri tidak terstruktur (KMTT), (5) Pelaksanaan penilaian ketrampilan 
(psikomotor), (6) Pelaksanaan penilaian Afektif akhlak mulia, (7) Pelaksanan penilaian Afektif kepribadian, (8) Program dan pelaksanaan Remidial, (9) Analisis hasil ulangan, (10) Bank Soal/Instrumen Tes.

Kisi-kisi instrumen kemampuan guru dalam melakukan penilaian administrasi pembelajaran mencakup 10 komponen yaitu: (1) Buku nilai/Daftar nilai (item no 1), (2) Pelaksaan Tes (kognitif): UH, UTS, UAS (item no 2), (3) Penugasan terstruktur (PT) (item no 3), (4) Kegiatan mandiri tidak terstruktur (KMTT) (item no 4), (5) Pelaksanaan penilaian ketrampilan (psikomotor) (item no 5), (6) Pelaksanaan penilaian Afektif akhlak mulia (item no 6), (7) Pelaksanan penilaian Afektif kepribadian (item no 7), (8) Program dan pelaksanaan Remidial (item no 8),(9) Analisis hasil ulangan (item no 9), (10) Bank Soal/Instrumen Tes (item no 10).

Tiap instrumen penilaian terdapat 5 kualifikasi penilaian yaitu 1, 2, 3, 4 dan 5 Setiap skor yang diperoleh kemudian dibagi dengan skor maksimal dan dikalikan dengan 100 atau setara dengan formulasi berikut: $\mathrm{N}=\frac{\text { skor yang diperoleh }}{\text { skor maksimal }} \mathrm{X} 100$.

Adapun kriteria penilaian yaitu: Baik Sekali berada di skor 91 sampai 100, Baik berada pada skor 76 sampai 90, Cukup berada pada skor 61 sampai 75, Kurang berada pada skor 51 sampai 60 sedangkan Kurang Sekali berada pada skor kurang dari 50. Selanjutnya dilakukan komparasi data untuk memastikan ada tidaknya peningkatan kemampuan guru dalam menyusun perencanaan pembelajaran, peningkatan kemampuan guru dalam pelaksanaan. Sebagai tolok ukur keberhasilan pelaksanaan penelitian tindakan kelas ini ditetapkan indikator kinerja sebagi berikut: 1) Persentase jumlah skor perolehan kemampuan administrasi penilaian pembelajaran sebesar $25 \%$.

\section{HASIL DAN PEMBAHASAN}

Supervisi akademik yang telah dilakukan nyatanya memberikan pengaruh signifikan dalam penyusunan administrasi penilaian pembelajaran. Skor capaian hasil penyusunan administrasi penilaian pembelajaran tersebut dirangkum dalam Tabel 1.

\section{Tabel 1 Komparasi Tingkat kompetensi}

Penyusunan Administrasi Penilaian Pembelajaran

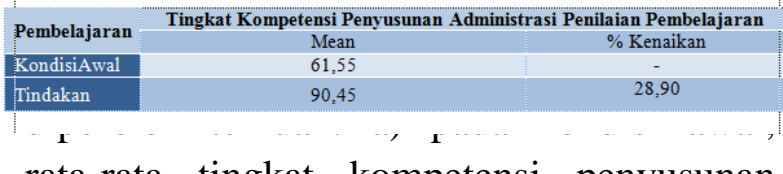

rata-rata tingkat kompetensi penyusunan administrasi penilaian pembelajaranbaru mencapai 61,55 (skor maksimal ideal 100); b) setelah diberikan tindakan, rata-rata kompetensi penyusunan administrasi penilaian pembelajaran mencapai 90,45. Data ini menunjukkan peningkatan kompetensi penyusunan administrasi penilaian pembelajaran sebesar $28,90 \%$.

Data yang ada pada tabel 2 berikut memberikan gambaran distribusi dan visualisasi skor kondisi awal dan setelah diberi tindakan.

Tabel 2

Distribusi FrekuensiTingkat Kompetensi Penyusunan Administrasi Penilaian Pembelajaran Kondisi Awal dan setelah Tindakan 


\begin{tabular}{|c|c|c|c|c|c|}
\hline \multirow{2}{*}{ Kategori } & \multirow{2}{*}{ Interval Skor } & \multicolumn{2}{|c|}{ Kondisi Awal } & \multicolumn{2}{|c|}{ Setelah Tindakan } \\
\hline & & $\mathrm{F}$ & $\%$ & & \\
\hline Baik Sekali & $91-100$ & - & & 5 & 45,46 \\
\hline Baik & $76-90$ & 2 & 18,18 & 4 & 36,36 \\
\hline Cukup & $61-75$ & 5 & 45,46 & 2 & 18,18 \\
\hline Kurang & $51-60$ & 4 & 36,36 & - & \\
\hline Kurang Sekali & $<50$ & - & & - & \\
\hline & & 11 & $100 \%$ & 11 & $100 \%$ \\
\hline
\end{tabular}

kompetensi penyusunan administrasi penilaian pembelajaran mengalami peningkatan. Hal ini bisa dilihat bahwa tidak ada guru yang tidak melaksanakan penilaian afektif, sudah melaksanakan tugas secara tertruktur, sudah melaksanakan program dan pelaksanaan remidial serta sudah melakukan analisis hasil ulangan, ada 5guru $(45,46 \%)$ pada kategori baik sekali, 4 guru $(36,36 \%)$ berada pada kategori baik dan 2 guru $(18,18 \%)$ berada pada kategori cukup.

Data pada tabel 1mengenai kompetensi guru pada kondisi awal dan tindakan menunjukkan temuan skor kemampuan guru dalam penyusunan administrasi penilaian pembelajaran kondisi awal 61,55dan pasca tindakan skornya mengalami peningkatan sebesar 90,45. Temuan ini mengindikasikan adanya peningkatan tingkat kemampuan guru dalam penyusunan administrasi penilaian pembelajaran. Besaran peningkatan $28,90 \%$. Jika dibandingkan dengan indikator kinerja $25 \%$ ternyata temuan tersebut telah mencapai keberhasilan. Temuan ini sejalan dengan penelitian Parwati Santi dkk (2013), Dalawi dkk (2012), dan Banun Sri Haksasi (2013).

\section{SIMPULAN DAN SARAN}

Berdasarkan hasil penelitian dan pembahasan, dapat disimpulkan bahwa supervisi akademik dapat:Meningkakan kemampuan guru dalam penyusunan administrasi penilaian pembelajarandi SDN 116884 Sei Kebara Desa Torgamba sebesar $31,4 \%$. Selanjutnya, saran yang diajukan dalam penelitian ini adalah, kepala sekolah hendaknya: a) menggunakan supervisi akademik untuk memperbaiki pembelajaran, dan b)melatih guru untuk berpartisipasi aktif dalam pengembangkan pembelajaran di kelas.

\section{DAFTAR PUSTAKA}

Arikunto, Suharsimi. 2006. Dasar-Dasar Supervisi. Jakarta: Rineka Cipta.

Banun Sri Haksasi. 2013.Pelaksanaan Supervisi Akademik Pada SMA Negeri 3 Semarang.Majalah Ilmiah Pawiyatan, $(\mathrm{xx}): 4$.

Dalawi, Amrazi Zakso, Usman Radiana. 2012. Pelaksanaan Supervisi Akademik Pengawas Sekolah Sebagai Upaya Peningkatan Profesionalisme Guru SMP Negeri 1 Bengkayang.S2 AP. FKIP Universitas Tanjungpura, Pontianak.

Danim Sudarwan dan Khairil. 2011. Profesi Kependidikan. Bandung: Alfabeta.

Daryanto dan Tasrial. 2011. Konsep Pembelajaran Kreatif. Yogyakarta: GavamediaSahertian. 2010. Konsep Dasar dan Teknik Supervisi Pendidikan dalam Rangka Pengembangan Sumber Daya Manusia. Jakarta: Rineka Cipta. 2010. Administrasi Pendidikan. Jakarta: Rineka Cipta. 
Bahasa Indonesia Prima, Vol 2. No. 2. 2020

e-ISSN: 2684-6780

Dirjen Peningkatan Mutu Pendidikan dan Tenaga Kependidikan. 2012. Pedoman Pelaksanaan Kinerja Guru (PK Guru). Buku 2. Jakarta: Kementerian Pendidikan dan Kebudayaan.

Parwati Santi Desak Putu, Dantes Nyoman dan Natajaya Nyoman. 2013. Implementasi Supervisi Akademik dalam Rangka Peningkatan Kemampuan Menyusun RPP pada Guru Matematika Sekolah DasarAnggota KKG Gugus IV Kecamatan Sukasada.e-Journal Program Pascasarjana Universitas Pendidikan GaneshaJurusan Pendidikan Dasar (3).

Pujiono. 2014. Laporan Pelaksanaan Supervisi Akademik. SD Kristen Satya Wacana.

Sudjana Nana dkk. 2011. Buku Kerja Pengawas Sekolah. Pusat

Pengembangan Tenaga Kependidikan. BadanPSDMdanPMP. Jakarta: Kementerian Pendidikan dan Kebudayaan.

Suhertian. 2000.Konsep Dasar dan Teknik Supervisi Pendidikan.Jakarta: Rineka Cipta.

. 2009. Undang-Undang Nomor 39 tahun 2009 Tentang Pemenuhan Beban Kerja Guru dan Pengawas Satuan Pendidikan. Jakarta. .2005. Undang-Undang RI No. 14 Th. 2005 Tentang Guru dan Dosen. Jakarta:Depdiknas.

. 2007. Peraturan Menteri Pendidikan Nasional No. 16 Tahun 2007 tentang Standar Kompetensi Guru. Jakarta:Depdiknas. 